University of Warwick institutional repository

This paper is made available online in accordance with

publisher policies. Please scroll down to view the document

itself. Please refer to the repository record for this item and our

policy information available from the repository home page for further information.

To see the final version of this paper please visit the publisher's website. Access to the published version may require a subscription.

Author(s): BERNARD CAPP

Article Title BIGAMOUS MARRIAGE IN EARLY MODERN ENGLAND

Year of publication: 2009

Link to published version:

http://dx.doi.org/ 10.1017/S0018246X09990021

Publisher statement: none 


\title{
BIGAMOUS MARRIAGE IN EARLY MODERN ENGLAND
}

\author{
Bernard Capp \\ University of Warwick
}

\begin{abstract}
Though divorce followed by remarriage was illegal in early modern England, a considerable number of people whose marriage had failed or whose spouse had deserted ventured to marry again, either uncertain of the law or choosing to defy it. Bigamy, traditionally a spiritual offence, came to be seen as a significant social problem and was made a felony in 1604. Drawing on ecclesiastical and secular court records and a variety of other sources, this article examines the legal framework, offers a typology of bigamists, and explores the circumstances surrounding their actions. It finds that offenders, predominantly male, ranged from the unlucky or feckless to the cynically manipulative, among them a small number of serial bigamists. It also asks how such offences might come to light in an age of relatively poor communications, and examines the plight of those who had married a bigamist in good faith. Finally it examines the likelihood of conviction, and the punishment of those who confessed or were convicted.
\end{abstract}


In June 1663 the young and beautiful Mary Carleton stood trial for bigamy at the Old Bailey. She was prosecuted by her husband John, furious at discovering that she was not the wealthy German princess he thought he had wed, and hoping to be rid of her by proving she was a lowly woman from Canterbury and already married to a shoemaker. Mary’s good looks and spirited defence made her a sensation, and Samuel Pepys (who had visited her in prison) was among many delighted to see her acquitted. ${ }^{1}$ But if this was the most celebrated bigamy trial of the period, it was by no means the rarity that her modern biographer supposed, and its themes of deception, opportunism, greed and malice recur in many other, less familiar cases.

Historians, with the notable exception of Lawrence Stone, have traditionally paid more attention to marriage-formation in early modern England than to its dissolution. We know that some unions ended in judicial separation (divorce a mensa et thoro) through the ecclesiastical courts. Some were annulled, when (for example) it could be proved that there had been a prior contract. Far more collapsed when one partner deserted, and many ended in limbo, with a man going to sea, to the wars, or to seek work, and simply failing to return. The law held that marriage was for life, and judicial separation did not allow the parties to remarry, though a deserted spouse could marry again if nothing had been heard of the absentee partner for seven years, after which he or she was legally assumed to be dead. ${ }^{2}$ In practice, however, is clear that a significant number of individuals ventured to remarry in ignorance or defiance of the law. Lawrence Stone once remarked in passing that there were probably thousands, perhaps tens of thousands, of bigamous marriages in seventeenth- and eighteenth-century England. ${ }^{3}$ These were figures plucked 
from the air, and Stone chose to explore two spectacular eighteenth-century cases in depth, rather than to address the general phenomenon. ${ }^{4}$ Yet he had a point; bigamy was no rarity. This article draws on over 350 cases from the later sixteenth and seventeenth centuries, from spiritual and criminal court records, newspapers and other sources, and explores the circumstances behind them and the response of the courts.

Some of those who fled a failing marriage chose simply to cohabit with a new partner, often pretending, or letting it be assumed, that they were properly married. The social fluidity and anonymity of early modern London meant that a couple might live together for years without detection. Robert Hawe and his partner had six children before it emerged in 1621 that they had never married. ${ }^{5}$ But many others opted to remarry bigamously, partly because any cohabiting couple was always in danger of unwelcome attention from neighbours and parish officers, especially in smaller communities. In practice, cohabiting couples were thus driven by social pressure either to pretend to be married, or to contract a bigamous marriage. While the second option made exposure less likely, it carried substantially heavier risks. Who were the bigamists? And how did the courts react when their offence was exposed?

First, the law. The ideal marriage was conducted publicly in the parish church of the bride or groom, by a minister, preceded by banns or with a licence. Many other forms of marriage were recognised as valid, however, even though those involved might incur penalties. Some couples married clandestinely, like William Bryan, a Worcestershire tailor married in a baker's shop in the 1590s by an unbeneficed minister. ${ }^{6}$ Others merely exchanged vows, sometimes without witnesses, a practice which carried the risk that one 
or both parties might subsequently repudiate their vows and contract themselves to another. $^{7}$ The law provided for judicial separation by an ecclesiastical court in cases of adultery or extreme cruelty, but divorce followed by remarriage remained impossible until the late seventeenth century; even then it was available only for the elite, by private act of parliament. Many more couples separated informally, and some turned to the secular courts to underwrite or enforce financial and maintenance arrangements. ${ }^{8}$

In the sixteenth century, as earlier, bigamy was merely a spiritual offence, prosecuted in the church courts. That changed in 1604, when parliament made it a felony. Offenders now faced the death penalty, except for those whose first spouse had been absent for seven years, and those who had previously secured a 'divorce'. The wording here was ambiguous. The legislators may have intended 'divorce' to mean annulment, as the crown's lawyers argued in King's Bench in 1636 in the case of Ann Porter, who had remarried only six months after securing a judicial separation. The defence counsel insisted that, while her new marriage was unlawful, the separation protected Porter from the penalties of the Act, adding for good measure that 'an ignorant woman' could hardly be expected to understand the difference between divorce and separation. The judges admitted that they too were unsure of the statute's meaning, and advised Porter to seek a royal pardon to guarantee her safety. Juries sometimes felt equally confused, but it was gradually established that separated couples were indeed protected by the Act. ${ }^{9}$ They were still barred from remarrying, of course, while any person who remarried after waiting the requisite seven years after their spouse had vanished would still find the new marriage invalidated should he or she subsequently reappear.. 
The new law had complex origins. In some respects, it was in line with other Elizabethan and early Stuart measures imposing harsher penalties for moral offences such as bastard-bearing and sodomy. But it also marked the final defeat of advanced Protestants and puritans who had long sought to bring English law into line with Reformed continental practice, where divorce and remarriage were permitted in certain circumstances. The biblical texts were ambiguous, and prominent early reformers such as William Tyndale, Thomas Becon, Bishop Hooper and Archbishop Cranmer were convinced by the scriptural case for divorce and remarriage on the grounds of adultery, desertion, or both. ${ }^{10}$ An attempt to incorporate the Reformed position through the Edwardian Reformatio legum ecclesiasticarum was thwarted by Elizabeth I and Archbishop Parker, but the theological debate resurfaced a generation later, when John Rainolds, the leading puritan academic in late Elizabethan Oxford, denounced existing law as 'popish doctrine', and defended the superior judgement of the Reformed churches. ${ }^{11}$ His tract, though unpublished, triggered a vigorous response from the Yorkshire minister, Edmund Bunny, who had been approached by a gentleman seeking permission to divorce an adulterous wife and remarry, and had already won the backing of several local clergymen. Instead of helping, Bunny preached a series of combative sermons condemning divorce and remarriage, and in 1595 penned a treatise on the subject which he sent to Archbishop Whitgift. The archbishop had blocked the publication of Rainolds's tract and similarly withheld permission from Bunny, anxious to avoid public controversy. ${ }^{12}$ It followed regardless. In 1601 Lancelot Andrewes, dean of Westminster, inveighed against divorce and remarriage, while John Dove, a leading city preacher, delivered a fiery sermon to the same effect at St. Paul’s Cross. John Howson, 
vice-chancellor of Oxford, published another attack in 1602, in Latin, which was promptly countered by the puritan polemicist, Thomas Pye. ${ }^{13}$

This scholarly debate was accompanied by growing concern about the number of bigamous, incestuous and other scandalous marriages taking place, at all social levels. It is clear that some laymen had long resorted to unauthorised remarriage. Some may have misunderstood the law, which invited confusion by using 'divorce' to cover both annulment (which invalidated an existing marriage and thus allowed a new one) and judicial separation. Others may have been influenced by Reformed opinion. Many, no doubt, were simply anxious to rid themselves of an unfaithful wife. Parliament had passed a special act in 1552 to confirm the remarriage of William Parr, marquis of Northampton, who had divorced his adulterous wife, and in the mid-Tudor period several citizens of Norwich, including an alderman, had also ventured to remarry. ${ }^{14}$ A generation later, Bunny observed that several northern gentlemen had recently done the same, and acknowledged that his exposition of current law had surprised some of his audience, including Henry Hastings, earl of Huntingdon and president of the Council of the North. ${ }^{15}$ These concerns flared up in the Parliament of 1597, when MPs exchanged horror stories about bigamous, incestuous and other irregular marriages, blaming them on the abuse of marriage licences, which allowed rogue clerics to connive at such unions. It was reported, for example, that Sir Edward Waldegrave of Suffolk had married one day, only for his wife to be carried away and married to another man the very next day, by licence. A Worcestershire man had married two wives, and subsequently murdered one. One Sermishair was said to have divorced two wives and then married the daughter of the bishop of Coventry and Lichfield, who was herself divorced from a former husband. 
Elizabeth I intervened in the debates, informing the Commons that she was scandalised by such reports and would take remedial action. ${ }^{16}$ Action soon followed. New canons in 1597, confirmed in 1604, restated traditional law and now required those judicially separated to give bond not to remarry during the lifetime of the former spouse. A testcase in Star Chamber in 1598 saw Whitgift and other eminent ecclesiastics and civil lawyers crush a landowner who had ventured to divorce and remarry (twice), and reaffirmed that remarriage was illegal. And the preamble to the 1604 Act stated bluntly that its purpose was to stop the practice of 'evil disposed' people going into other counties and contracting new, clandestine marriages. ${ }^{17}$

There was thus a long-standing tension between ecclesiastical law, the views of some puritans, and the attitudes of at least part of the lay population. The 1604 Act, perhaps inevitably, did not wholly resolve that tension, and the theological debate continued. When Rainolds's tract was published (abroad) in 1609, shortly after his death, Bunny published his counter-blast, acknowledging, however, that 'many of the learned have been, and yet are', of a contrary view. In 1619 William Whately, the puritan minister of Banbury, asserted the right of the innocent partner to remarry, in cases of desertion or adultery, though he was forced to publish a humiliating retraction a few years later. ${ }^{18}$ Some laymen also proved defiant, most notably Elizabeth I's former commander in Ireland, Charles Blount, Lord Mountjoy. After living for years with the estranged wife of Lord Rich, Mountjoy married her after Rich divorced her in 1605, and persuaded William Laud, future archbishop of Canterbury, to officiate. Mountjoy then begged the new king, James I, to condone his action, presenting a memorandum which rehearsed the biblical and theological arguments for remarriage. His pleas unheard, the 
scandal ended his political career. ${ }^{19}$ A generation later, the civil war brought new confusion. The upheavals of war inevitably left many families broken and scattered, and the ecclesiastical courts no longer functioned. John Milton issued several tracts in support of divorce and remarriage, while some radical separatists abandoned their 'ungodly' spouses to marry a co-religionist. Thomas Edwards, the heresiographer, reported in 1646 the alarming belief that ' 'Tis lawfull for one man to have two wives at once', while in 1653 Barebone’s parliament passed a short-lived law making marriage a secular contract, and debated a clause which would have allowed divorce and remarriage for the innocent party in cases of adultery. Most of the population deeply resented the new arrangements, and many couples arranged illegal clandestine marriages by ministers, instead of, or as well as, the civil ceremony conducted by a justice of the peace. ${ }^{20}$

\section{II}

The true scale of bigamous marriage in early modern England will never be known. Most bigamists naturally tried to cover their tracks, and many may well have succeeded. They usually moved to a new location, hiding behind a plausible narrative and often assuming a new identity. ${ }^{21}$ Some obtained forged documentation. Richard Puncheon, a Kent miller, had already abandoned two wives (in Essex and Surrey) when he decided to marry a third in 1601, assuring her that he was a widower. When asked for proof, he went to London and obtained a certificate with the forged signature of a minister to confirm his story. ${ }^{22}$ Similarly, a Middlesex shoe-mender forged a certificate in 1656 affirming that his forthcoming marriage had been openly published, as the law

required; in fact, both he and his intended bride were already married. ${ }^{23}$ Several men tried 
to avoid exposure by paying the first wife to deny their marriage, or by paying another man to claim her as his own. ${ }^{24}$ A few went still further. John Gower, a bigamous coachmaker, was so desperate to be rid of his first wife that he offered another man $£ 5$ to seduce her, to secure grounds for a divorce; and when this ploy failed, he shot her in the head at Hampstead. ${ }^{25}$

What sort of people became bigamists? A typology might begin with the innocents who had married in good faith, only to discover that a long-absent spouse assumed to be dead was in fact still alive. That situation was sufficiently familiar to prompt a jest in 1654 about a man who had reappeared after many years to claim back his wife, since married to another. A magistrate summoned the three before him, and invited the wife to choose whichever she pleased. After scrutinising them carefully she replied, 'May it please your worship sir, I hope I shall please them both' ${ }^{26}$ In reality, of course, the predicament was far from comical. One Leicestershire villager deposed in 1602 that his first wife had vanished only a year after their marriage, over twenty years earlier. After waiting seven years he had married again, in church, assuming that she was dead. But after sixteen years together, it emerged that his first wife was still alive, and an ecclesiastical court ordered him to return to her. ${ }^{27}$ Alice Green of Leicester offered a similar story. Her husband had vanished for fifteen years before reappearing suddenly in May 1620, when he stayed only half an hour. As a consequence of this brief, unwelcome resurrection, Alice, who had re-married three years earlier, was bound over to appear at the assizes. ${ }^{28}$ Predictably some couples found it hard in such circumstances to give up a much stronger, new relationship. Mary Deane, for example, had married in London in 1597 after hearing that her first husband was dead. Subsequently, however, on hearing 
reports that he was still alive, she travelled home to Scotland to find that this was indeed the case, whereupon she very properly obtained a divorce from Deane in the Court of Arches. But she proved unable to end the relationship, enjoying secret trysts in the lodgings of a friend and using a secret cipher to conceal her activities. After lengthy examinations, the Bridewell Governors ordered her to be whipped and sent back to Scotland. $^{29}$

Alongside the innocent stand the naïve, feckless and casual. Millicent Alberd, of St Giles in the Field, confessed in 1576 that she had been married three times, only to discover that each husband was already married. All she could offer by way of defence was that 'she is not the first that hath been deceived'. ${ }^{30}$ Perhaps she had asked few questions. Historians have stressed the central importance of marriage and the family in early modern society, reflecting the values of the respectable 'middling sort' at whom the domestic conduct manuals were chiefly aimed. But not everyone shared such values, and those living in a precarious economy of makeshifts might well bring a similarly makeshift approach to personal relationships. Thus Agnes Williamson of Charterhouse Lane, accused in 1579 of having three husbands and committing adultery with a journeyman shoemaker, tried to mitigate her offence by explaining that she had left one husband, a minstrel, on discovering that he was already married. The court was unimpressed. ${ }^{31}$ A disgruntled Wiltshire man, petitioning in 1648 to be freed from a woman he had married in good faith, alerted the authorities to an alehouse-keeper with two wives, one of whom allegedly had three husbands. ${ }^{32}$ Similarly, some men and women who remarried after being deserted had not tried very hard to establish that their former spouse was actually dead. When Henry Carricke fled Portsmouth, heavily in debt, 
his wife waited only a year before marrying again, in 1663; happy to believe a rumour that he had died at sea, she had made little attempt to establish the facts. ${ }^{33}$

The ‘sacred ties' of matrimony might thus count for very little, especially among the urban and migrant poor. William Goffe of Whitechapel confessed to marrying two women in September 1652 on successive days. ${ }^{34}$ Three years later, a newspaper reported the more elaborate story of a Shoreditch man who had remarried only three weeks after his wife's death. His new wife, an opportunist, absconded a few days later, taking his former wife’s best clothes and $£ 15$ in money. Within a few weeks the bereft husband had recovered sufficiently to marry yet again; whereupon his runaway wife reappeared, brandishing the marriage certificate, in the hope of extorting money by threatening to report him for bigamy. ${ }^{35}$ As we might expect, casual relationships were common among the disorderly ranks of beggars, vagrants and criminals. ${ }^{36}$ Richard Brandon, the hated Tyburn hangman, was said to have been condemned twice for bigamy, and twice reprieved. ${ }^{37}$ And when Jenny Voss, the notorious thief, was hanged at Tyburn in 1684, it was noted that 'according to report no less than 18 of her reputed husbands or friends had suffered for their robberies'. Among them was her most recent 'husband', though the reporter was unsure whether their relationship was based merely on 'taking one another's word, or making a Westminster [i.e. clandestine] wedding of it' ${ }^{38}$ In this milieu, 'husband' and 'friend' were clearly loose, almost interchangeable categories.

It would be wrong, however, to associate bigamous marriages too narrowly with these marginal groups. The story of Bettrice Boddye, prosecuted in 1600, reminds us that even 'middling-sort' status was not necessarily secure, and that shifts of fortune might prompt a cynically ruthless pragmatism. Married at fifteen, Bettrice soon discovered that 
her husband was already married, and thereupon secured an annulment through the help of a lawyer, Thomas Boddye, who then married her himself. After an apparently stable life together for eight years, Boddye divorced her for reasons unknown, and married another wife. Bettrice thereupon married another husband, and when he died, a fourth, whom she soon abandoned when he proved unable to maintain her. Boddye then reappeared, and the couple resumed cohabitation for a time, and had a child. But by May 1600 they had separated again, and she had married yet another man and was carrying his child. The first marriage had been void, but at the time of her interrogation she had three husbands living; and two of her partners were themselves bigamists. Boddye, the lawyer, was himself questioned a few weeks later over allegations that he was sleeping with his housekeeper, and was ordered to stay away 'unless he marries her'. ${ }^{39}$ Were the Bridewell Governors themselves unsure what the law permitted? Or did they lack the bureaucratic skills to connect the two cases? Both possibilities are suggestive.

Another, perhaps overlapping category of offenders were those uncertain about the law's requirements. As already noted, some layfolk believed that remarriage was permitted after divorce a mensa et thoro, and this view can be found at all social levels; indeed, some claimed that ministers had given them advice to that effect. In 1578, William Hunter, a porter, explained to the Bridewell Governors that he had secured a separation from his wife in the church court 'because she played the harlot'. They had since both remarried, and Hunter may well have believed that he had been entitled to do so. ${ }^{40}$ Anne Kellam, who had three young children by her partner, similarly explained in 1602 that he had assured her that 'if he could by the laws of the land put away his wife he would make [her] his wife,' affirming (without any apparent sense of irony) that he could 
secure a divorce by proving that his wife 'was dishonest of her body' ${ }^{41} \mathrm{~A}$ few couples had resorted to informal methods of divorce and remarriage. The Elizabethan pamphleteer Robert Greene, narrating the life of a famous cutpurse, shows the rogue-hero swapping wives with another man, and dismissing their informal remarriages as mere 'trifles'. ${ }^{42}$ Not all such ‘folk divorce’ were consensual, however. John Manning of Chick Lane explained in 1600 how his wife had fallen in love with another man, who had then threatened to kill him 'except he let her goe, whereuppon he turned her away and did not see her since'. She had then married her rough wooer, whilst Manning himself was now planning to marry again. ${ }^{43}$ Katherine Noade preferred a different arrangement, admitting in 1598 that she had two husbands and lay sometimes with one, sometimes the other. ${ }^{44}$ If polyandry was rare indeed, many contemporaries were uncertain about what the law allowed, and perhaps indifferent.

The majority of bigamists, however, belonged to another category: people moving on from an old or failed relationship, and hoping to make a permanent commitment to a new partner- the pattern we now label 'serial monogamy'. Many had been accidentally separated from their wives or husbands, and after years apart hoped or assumed that their former partner was dead. ${ }^{45}$ Some of the cases that eventually came to light involved gaps of ten, twenty or even thirty years between the two alleged marriages, and equally striking physical distances: between Herefordshire and Kent, for example, Surrey and Derbyshire, Dorset and Lancashire, Dublin and Westminster, even London and Barbados. ${ }^{46}$ In many other cases, one partner (usually the husband) had deliberately left in order to escape a failed marital relationship. Once having found work in a new 
location, he could easily pass himself off as single or a widower, and establish a new relationship.

A final, and much smaller, category comprises serial bigamists: individuals who deliberately deceived and then abandoned their victims. The Rev. William Smith, for example, married a young woman in Cornwall in 1655 and then absconded, taking his patron’s horse and £20. Searching his papers, his wife found references to six other women he had previously married and abandoned, as far apart as Somerset, Norfolk and Northumberland. A description was circulated in the press, and six months later it was reported that a minister answering it had been arrested in Westminster. ${ }^{47}$ Another rogue clergyman confessed at the Old Bailey in 1651 to having three or four wives, and a third was convicted in 1684; both were sentenced to be branded. ${ }^{48} \mathrm{~A}$ few serial offenders appear to have enjoyed even more extraordinary careers. In March 1652 a newspaper reported the case of a woman condemned to death at Reading Assizes for having fifteen husbands (though reprieved after pleading pregnancy), while one Hopkins was indicted at Northampton assizes in 1653 for having nineteen wives. ${ }^{49}$ The faithfull scout reported in July 1653 that one Gibson had been executed at Southampton for having twenty-seven wives, and that Ann Fletcher had been arraigned for having thirty-nine husbands. ${ }^{50}$ This was not the most reliable of newspapers, however, and these reports may owe more to moral panic or sensationalism than to hard evidence. Better documented is a shoemaker alleged to have seventeen wives and indicted over four at the Old Bailey in 1676. A handsome journeyman with a plausible manner, he had travelled around the country for five years pretending to be a person of birth and estate, with considerable success. Pleading guilty to all indictments within benefit of clergy, he begged to be transported; 
but the bench, unmoved, sent him to the gallows. ${ }^{51}$ While few offended on such a scale, we can find several other men (and a few women) cast in a similar mould. John Paydon, convicted of 'polygamy' in December 1699, had recruited an accomplice to bolster his claim to be a man of property, and was a fraud on several counts, boasting of extraordinary healing powers as the seventh son of a seventh son. ${ }^{52} \mathrm{~A}$ few women pursued a similar course. Mary Stoakes (who like Paydon used many names) was convicted in 1692 of marrying two men within four years, and of now passing herself off as a maid with a substantial estate in the hope of snaring another. ${ }^{53}$

Finally, we may note that allegations of bigamy might also surface in other contexts, especially after 1604 . To smear an opponent as a bigamist could badly damage his or her reputation, and though it was not commonly employed it is unsurprising to find individuals sometimes suing for defamation or slander. ${ }^{54}$ Opportunists also scented an attractive prospect for fraud and extortion. In 1620 four Sussex villagers seized a man under colour of forged letters patent, accused him of bigamy, and held him captive for two days until he paid them $£ 8$ to secure his release. In 1658 a Holborn tailor was prosecuted for offering a man $£ 100$ to swear that Elizabeth Brett, a married woman, had a second husband. ${ }^{55}$ Innocence, of course, did not guarantee safety in an age when witnesses could easily be bought. And occasionally the bigamists themselves appear to have been the victims of greed and manipulation. Thus Samuel Rumny, who confessed in 1681 that he had married a second wife in Boston, New England, claimed that he had been led astray by her 'lascivious and wicked practices'. She had talked him into both marriage and impersonating a knight, since when, he complained, she had several times sought to take away his life and 'had been a continual torment to him'. It would seem that 
she was also behind the indictment. Though his story cannot be confirmed, his second wife possibly thought him a gullible pawn, hoped the imposture would make money, and then sought to be rid of him when the scam failed. ${ }^{56}$

Bigamy thus covered a wide range of circumstances, and we can find offenders ranging from labourers to gentlemen. In the cases that have come to light, men clearly outnumbered women, by a ratio of over four to one (17 men: 4 women) in bigamy trials in Essex, over three to one (23:7) in Kent and in late-seventeenth-century trials at the Old Bailey (41:12), and two to one in the cases examined by justices in interregnum Middlesex (62:35). ${ }^{57}$ It was far easier for men to find work in a new area, especially for journeymen and labourers, while soldiers and sailors were traditionally associated with both mobility and transient relationships. By contrast, a woman with small children would find it emotionally hard to leave them, and almost impossible to find work if she took them with her. A woman was also much less likely to have ready cash for expenses at her disposal, and any woman travelling alone was likely to face questioning by suspicious local officials. A woman alone was not usually permitted to take lodgings, and any woman 'living at her own hands' might be prosecuted or turned out of the town or parish. If permitted to stay, she would generally be required to go into domestic service, which might leave her situation no better than before. These were powerful disincentives. Many female bigamists appear to have been, to some extent, victims of circumstance, marrying again after having been left by a husband they later assumed or hoped was dead. Others had left home only after having already found a new partner, so that they could continue to function as part of a couple; men, by contrast, often established a new relationship only after they had settled in a new location. 
So much for the bigamists. What of their abandoned spouses? A deserted wife would often try hard to trace her missing partner, hoping to make him return or at least provide some maintenance. But it was hazardous for a woman with little money to travel alone, for she might easily be assaulted, or arrested as a vagrant, or indeed turn into one. Anne Jenkins, arrested in London in 1630 for vagrancy, had been taken in men's clothing, 'which she saith she wore to look for her husband who was gone from her and about to take another wife'. ${ }^{58}$ Those with greater resources preferred less dangerous remedies. When a coachmaker's wife in Whitechapel learned in 1652 that her runaway husband had recently married again, with twenty coaches accompanying him to the wedding, she inserted a newspaper advertisement offering a large reward for information about his current whereabouts. ${ }^{59}$ By contrast, poorer women would often track down and confront the new 'wife' in the street, hoping to shame or frighten her into ending the relationship. Thus in 1651 we find Katherine and Joan Lovegrove both bound over to keep the peace, 'both of them continually fighting when they meet about one husband challenged by them both'. ${ }^{60}$ Others notified a local magistrate, hoping he could bring pressure to bear or with a view to prosecution. ${ }^{61}$ One exceptional woman, enraged, confronted her bigamist husband and stabbed him to death. ${ }^{62}$

The bigamist's new partner might also be an innocent victim, having married in good faith, and the combination of increased social mobility and a paucity of documentary evidence made such traps all too common. Edmund Palmer, a tailor prosecuted in 1575, was one such victim. Originally from Somerset, he had moved to Kent where he married, only to discover that his wife had two other husbands still alive. ${ }^{63}$ 
Margaret Chiseldon of Canterbury, another victim, had married a journeyman shoemaker in 1598, a newcomer to the town, who abandoned her only two weeks later; it soon emerged that he already had another wife, whom he also abandoned to move to London. ${ }^{64}$ Young journeymen were a highly mobile group, and migration to the capital, with its lures of opportunity and anonymity, was a rapidly increasing phenomenon.

When damaging rumours began to circulate, a new spouse would face an uncomfortable dilemma. Hard evidence was usually lacking, and such rumours often proved unfounded. Some new partners nonetheless chose to err on the side of caution. Mary Moore, married to a clergyman in Leicester in 1643, left him two years later after rumours that he already had a wife, and refused to return unless he could clear his name. All witnesses accepted that Mary herself was a gentlewoman of impeccable character, a victim not an accomplice. ${ }^{65}$ Other women simply dismissed unwelcome rumours and clung defiantly to their new relationship. Grace Daniell of Whitechapel, for example, ignored neighbours who told her that her new husband already had not one, but two, wives still living, and the relationship ended only when the pair were arrested and committed to Newgate. ${ }^{66}$ Similarly Johane Davies stood by her new husband, a London tailor, even after his first wife came to explain how he had abandoned her and their children. ${ }^{67}$ Mary Peate alias Meggs, accused of adultery with Sir Edward Norton, Bt., survived that hurdle only to face a new trial in 1653, this time for bigamously marrying her lover. ${ }^{68}$

\section{IV}

Bigamous marriages posed an obvious threat to the social order, and the severity of the 1604 Act was designed to deter, as well as to punish, offenders. Moreover both church 
and state were eager to see marriage regularized as a public ceremony, and by the early seventeenth century they had largely succeeded in suppressing matches based on mere verbal exchanges. The publication of banns certainly helped to alert both neighbours and the authorities to potential dangers. Two Cambridgeshire villagers, Anthony Warren and Mary Gybbs, had been called twice in 1605 when someone objected that Mary’s first husband was still alive, and the wedding was blocked until Anthony was able to confirm that her first husband had died in Ireland some years earlier. By contrast, similar objections against a London couple in 1637 proved well founded; it was established that the man did indeed already have a wife still living, whereupon he and his new partner were both prosecuted for fornication. ${ }^{69}$

While banns undoubtedly helped to expose irregularities, we may still wonder how so many bigamous marriages came to light in an age of poor communications. In small rural communities, inhabitants were often deeply suspicious of newcomers, prompted both by moral concern and the financial burdens that irregular families were likely to bring. Parishioners often demanded to see proof that a couple were properly married, especially if they were outsiders or had not married in the parish church. Any suspicious circumstance might be enough to persuade the churchwardens to make a presentment. When the churchwardens of Shepshed in Leicestershire presented a newlywed couple in 1602, they noted simply that both partners' former spouses were 'not known to be dead'. ${ }^{70}$ Bigamy was much more likely to be exposed in rural parishes, especially in lowland, fielden areas, than in large towns. Churchwardens often presented on the basis of generalised suspicions and rumour; prosecutions after 1604, by contrast, were frequently triggered by the family of the abandoned spouse, or the family of the 
second spouse, outraged at discovering the deceit. A female prosecutor (and her family) would be anxious to protect her good name, and to secure some financial provision. A male prosecutor might be looking in part to cover humiliation or exact revenge. A journalist reporting one Old Bailey case noted that the prosecutor had seemed remarkably eager to see his wife hanged. ${ }^{71}$

It may well be that many bigamists remained undetected. John Smith, a Cambridgeshire villager, had lived with his 'wife' for nineteen years before it emerged, around 1600, that they had never married. The law never caught up with a Cheshire woman who ran away from her home in Bunbury and married another man. A contemporary remarked that God's justice had proved harder to evade, for she eventually died a miserable and lingering death in 1631, after her 'secret parts ... rotted away'. ${ }^{72}$ The ‘dark figure’ of unreported cases was almost certainly highest in the capital. There offenders might well remain undisturbed for years unless they invited attention by rash words or foolish boasts, ${ }^{73}$ or by provoking their neighbours on other grounds. Thus a Ruislip man, accused of bigamy in 1653, was also accused by his neighbours of victualling without licence, and of entertaining lewd persons in his alehouse. Would they have reported him had he lived more quietly? ${ }^{74}$ Several other alleged bigamists faced simultaneous charges of theft or other offences; in such cases the local community, viewing them as undesirable neighbours, was probably exploiting every available weapon to be rid of them. ${ }^{75}$ In other cases, accusations may have been triggered by malice, rather than by moral concern. Thomas Hills, an Aldgate farrier, was accused in 1651 of having married his wife Rachel 'many years since', despite knowing that her previous husband was still alive in Barbados. Since the informant did not explain why he had waited so 
long before reporting the fact, he may have been exploiting a rumour to pursue a personal feud. $^{76}$

The rapid expansion of both internal migration and commercial links also meant, however, that no bigamist couple could be sure of remaining undetected, regardless of the lapse of time or distances involved. By the mid-seventeenth century, carriers were travelling weekly between most provincial towns and the capital. Most villages had former inhabitants who had moved to a larger town, or to London, and still remained in contact with families left behind. Dealers travelled around provincial markets, chapmen (and women) brought news as well as goods to even the smallest communities, and drovers, like soldiers and sailors, carried stories over far greater distances. This was a society in which information, like people, travelled more freely than ever before.

\section{V}

The prosecution of bigamy was transformed by the 1604 Act, though some overlap can be found between ecclesiastical and secular action much earlier. In London, the Bridewell Governors exercised wide jurisdiction over sexual offences, and magistrates everywhere felt authorised to investigate any offence against public order. One female bigamist was even presented by a manorial court jury at Southampton in $1603 .^{77}$ At Leicester, a suspect was interrogated by the mayor in 1600, before being passed to the church authorities for sentence when he finally confessed. ${ }^{78}$ The two authorities frequently worked in tandem. Randall Swetnam, a Gloucestershire minister accused of both adultery and bigamy, was delivered to the High Commission in March 1577, while his second wife was detained in the London Bridewell for hard labour. ${ }^{79}$ 
Both before and after 1604, allegations often surfaced without firm evidence. In such circumstances, magistrates would either dismiss them or order the accused or the accusers to supply proof. Suspects were frequently able, in time, to disprove damaging rumours against them. ${ }^{80}$ Robert Fox, a Leicester scrivener presented in 1614 for planning to marry despite a 'common fame' that he was already married, challenged the fame, and was thereupon ordered to purge himself by four compurgators. ${ }^{81}$ When Thomas and Katherine Franck were presented in 1586, Katherine explained that her first husband had abandoned her five years earlier, and that she had believed he was dead; they were ordered to live apart until the facts were established. ${ }^{82}$ Secular magistrates would sometimes detain suspects while such enquiries were carried out. Thus the mayor of Norwich committed a man to the house of correction in 1634, while his wife sought evidence to substantiate his claim that his former wife had died in Suffolk. ${ }^{83}$ Some magistrates took the task of investigation upon themselves. In 1612, for example, when a Peterborough man was accused of having a previous wife still alive in Leicester, a local justice wrote to the mayor to make enquiries. ${ }^{84}$

When evidence appeared sufficient, suspects (after 1604) would be indicted and stand trial. Very few admitted guilt. ${ }^{85}$ Most firmly denied the charge, and many were acquitted. In Essex assize cases under James I, four of the eight cases ended with a conviction or confession, as did thirty of fifty-five recorded trials at the Old Bailey between 1674 and $1700 .{ }^{86}$ By contrast only seven of the thirty cases before the assize courts in Kent between 1604 and 1688 resulted in convictions. When we examine the seven convictions, we find that in three cases the accused had remarried within a matter of weeks or months, making it relatively easy to produce documentary evidence and 
witnesses. Those acquitted, or dismissed by the grand jury, had generally faced allegations over marriages five, ten or fifteen years apart. The only woman convicted in Kent was also charged with grand larceny at the same assizes, and the only offender sent to the gallows was a man also convicted of stealing four cows and a flock of sheep. Juries would be much less sympathetic in such circumstances. Two other men, convicted despite alleged bigamous marriages that were ten years apart, had been tried at the same Maidstone assizes in July 1635, and we may suspect that an unusually stern judge helped shape the outcome. ${ }^{87}$ In many trials, the accused denied not one but both alleged marriages, and it is unsurprising that many prosecutions failed. ${ }^{88}$ When the first marriage had been many years earlier and far away, it was inevitably difficult to obtain conclusive evidence, and key witnesses frequently failed to appear in court. An old man who was prosecuted at the Old Bailey in 1691 and refused to acknowledge or deny either of the marriages alleged against him, telling the jury 'they might do what they would', was acquitted despite his truculence. ${ }^{89}$ Quite often, suspects who had allegedly confessed when initially questioned insisted on their innocence when indicted, having grasped the danger they were in and the evidential problems that faced the prosecution. ${ }^{90}$ Catherine Lile, for example, alleged second wife of a man tried at the Old Bailey in 1687, retracted an earlier confession and maintained that they had merely lived together; in consequence the man was acquitted, though the court, convinced that she was lying, dispatched her to the house of correction. ${ }^{91}$ Many acquittals were in effect 'not proven' verdicts, and recognised as such, with the accused sometimes ordered to provide sureties for their good behaviour. $^{92}$ 
Juries were clearly reluctant to send bigamists to the gallows. Faced with conflicting stories and inconclusive evidence, they generally gave the accused the benefit of the doubt. Margaret Haines, aged 70, told in 1681 how her first husband had abandoned her eighteen years earlier, and how she had eventually married a second husband who proceeded to spend all her money and then indicted her for bigamy, hoping to take away her life and so be rid of her. Taking pity, the bench directed the jury to acquit her. ${ }^{93}$ Others were perhaps luckier to escape. One prosecutor produced a Middlesex justice's clerk, who swore that the accused had confessed, while boasting that her second husband would never testify against her. In court, she denied any second marriage, and claimed that her (first) husband had brought a malicious prosecution so that he could be rid of her in order to marry another. The jury accepted her story. ${ }^{94}$ Daniel Minace of Westminster escaped in 1686 on a very different plea, by claiming that he had been tricked into marrying his second wife, while drunk. ${ }^{95}$

In the later seventeenth century, juries were undoubtedly influenced by the lax moral climate of the time, and by the ubiquity of clandestine marriage, especially in London. The incumbents of St James’s, Duke’s Place and Holy Trinity in the Minories, both exempt from episcopal oversight, were plying a massive trade in marriages without banns and licences, and when these loopholes were closed, the trade moved to the Fleet prison chapel, where by 1700 up to 2000 couples were marrying each year. Many such marriages were irregular or fraudulent; blank licences were readily available, and accommodating ministers were happy to change names and dates to oblige their clients. A proportion of such unions were almost certainly bigamous; more important, as it was generally recognised that many contemporary marriages were irregular, cases that came 
to light created little sense of shock. ${ }^{96}$ The moral climate was clearly reflected in the trial of Daniel Conduit in 1692, charged with having married two women within a few months. The first marriage was to Katherine Conway at Knightsbridge chapel, and the clerk produced the parish register in court to confirm it, but then conceded that 'it was usual for people to come there and personate others, and to make sham marriages'. Katherine claimed that Conduit had later abandoned her to pursue an heiress. For his part, Conduit denied ever having married Katherine, while admitting they had lived together; his own story was that she had heard of the other woman’s fortune, and had brought a malicious prosecution in the hope of securing a share. Both versions were all too plausible. $^{97}$

Nonetheless, juries did prove ready to convict when evidence was strong. Thomas Woodham initially protested his innocence, but presented with overwhelming evidence that he had married two women within two months in 1688 resorted to a plea that he had been drunk on both occasions. Richard Boile was convicted despite attempting to conceal his first marriage by bribing his wife to disclaim it. John Ogle, tried in 1693, denied his first marriage in Yorkshire, and claimed he had merely lodged with his alleged second wife at an inn. The prosecution, however, unusually well-prepared, was able to produce the marriage certificate and sufficient corroboration to secure his conviction. ${ }^{98}$

\section{VI}

What happened to those who confessed or were convicted? Before 1604, those sentenced in the spiritual courts were made to perform public penance. In 1602 a Leicestershire couple were ordered to do penance in white sheets at Lutterworth and Hinckley markets as well as in the parish church. ${ }^{99}$ Offenders might also face further punishment by the 
secular authorities, especially in London. Thus Henry Egerman, accused of contracting marriage with several women and of marrying at least two, was sent to Bridewell in 1562 by the bishop of London for additional punishment. Similarly in 1578 Thomas Brewer, who had already performed public penance, was sent in by the High Commission for further punishment, and was whipped along with his second wife (for her 'lewdness' with him). ${ }^{100}$ The crackdown that year saw two other men who had already performed penance at St. Paul's Cross passed on to Bridewell to be whipped. ${ }^{101}$ Agnes Williamson, accused of adultery as well as having three husbands, was sentenced in August 1579 to be whipped at a cart's tail through the streets, with two men condemned to similar double punishments. ${ }^{102}$ Bigamy was already seen as a significant threat to public order, warranting heavier punishments than the church could impose, and that sentiment helps to explain why the 1604 Act came into being.

Those convicted after the Act were generally allowed to claim benefit of clergy and, if successful, were burned in the hand. This was the standard punishment throughout the century, and in its later decades women, too, were sometimes granted benefit. ${ }^{103}$ But death sentences and executions did occur, especially in the earlier decades. ${ }^{104}$ Particularly flagrant offenders could expect no mercy. The shoemaker with seventeen wives was condemned to death, and so was Mary Stokes, convicted in 1693. The court heard that she had a further two husbands, and had been convicted on another bigamy charge only six months earlier. She had stayed with one husband only a single night. The court judged her 'an idle kind of a Slut, for she would get what money she could of them [her husbands], and then run away from them.' A calculating recidivist could expect to pay the price. ${ }^{105}$ The courts might also deny mercy to bigamists charged also with other 
offences, like a Kent labourer condemned in 1653 for bigamy and stealing livestock. ${ }^{106}$ Occasionally less flagrant offenders also went to the gallows, including men who had made voluntary confessions and might have hoped for mercy. ${ }^{107}$ Some were hanged after claiming benefit of clergy and then failing to read, such as an Essex chair-maker in 1617, a Stepney tailor in 1651, a simple 'country fellow' in 1676, and one Richard Hazlegrove in 1677. A court reporter conceded that Hazelgrove's fate 'seems a little severe, but so the law directs', and observed that his example might persuade idle children to 'study at least to read well'. ${ }^{108}$

Female offenders fared rather worse than men. Two of the five women found guilty at the Old Bailey in 1674-1700 were sentenced to death, compared to four of twenty-five men. Women suffered from the law's inherent bias (being ineligible for benefit of clergy until the law was amended in 1691), and a pervasive double standard. Two women were condemned to death at Surrey assizes in 1605, though both were temporarily reprieved after pleading pregnancy. Both had married bigamously in September 1604 , only a few weeks after the new statute came into effect. ${ }^{109}$ Dorothy Devison of Loose, Kent, condemned in 1644, had married twice within a few weeks the previous year, and was also charged with grand larceny. ${ }^{110}$ Another woman was condemned in 1676, after the Old Bailey magistrates refused to allow her benefit of clergy. ${ }^{111}$ A cluster of cases in the 1640 s and 1650 s appears to reflect a hardening of attitudes during the Puritan Revolution, affecting both men and women. Two women from Stepney were condemned to death in 1651, amid a flurry of cases that undoubtedly owed much to the moralistic zeal of the notorious local Justice Waterton. ${ }^{112}$ Female bigamists were also sentenced to death at Exeter in 1650, Reading in 1652, and Great 
Yarmouth in $1653 .{ }^{113}$ But later in the century it was very rare for a woman to be convicted on this charge, and the few exceptions were more likely to be branded, like male offenders, than hanged. ${ }^{114}$ Of the six recorded death sentences imposed at the Old Bailey in 1674-1700, four were clustered in 1676-7, with the other two in 1693. By the end of the century, hanging was a penalty rarely imposed. One male offender was transported in $1697 .{ }^{115}$

\section{VII}

Bigamy in early modern England was clearly practised on a scale far greater than in modern times, when divorce and remarriage have become relatively easy and cohabitation is socially acceptable. It was always a gender-related offence, for men found it much easier to migrate, obtain work and establish a new relationship, a pattern reinforced by the increased mobility of the period. The upheavals of the civil war period disrupted many marriages, and led to many more that were irregular. Many offenders were to some extent the victims of circumstance, accidentally separated from their first spouse and assuming after years of silence that he or she was probably dead. Others had deliberately abandoned a failed relationship, embarked on a new one, and hoped by an illicit marriage to remain undetected. Some were confused about what the law allowed, whether by the ambiguous connotations of the term 'divorce' or swayed by reports that the bible, some foreign states, and several of England's North American colonies allowed divorce and remarriage in certain circumstances. Luther and Martin Bucer had regarded bigamy as less sinful than divorce, and permissible in some contexts, and the view that bigamy and polygamy were sanctioned by the Old Testament surfaced periodically throughout the early modern period. ${ }^{116}$ Bigamy also needs to be seen within the wider 
context of irregular and clandestine marriage, which reflected an enduring tension between popular attitudes and the law. The eighteenth and nineteenth centuries saw local communities becoming increasingly sympathetic towards bigamous marriages in the context of marital breakdown or long-term separation, provided the first wife was not left destitute, and the courts themselves became more lenient. ${ }^{117}$ The 1604 Act, designed to suppress the practice of bigamy and end the debate over divorce and remarriage, fell short on both counts. While a few unlucky offenders went to the gallows, a minority of dissident voices continued to challenge the very principle on which the law was founded and popular attitudes remained ambivalent.

\section{FOOTNOTES}

1 See Mary Jo Kietzman, The self-fashioning of an early modern Englishwoman. Mary Carleton's lives (London, 2004), esp. pp. 37-77, for a full account of the case.

${ }^{2}$ Martin Ingram, Church courts, sex and marriage in England, 1570-1640 (Cambridge, 1987), pp. 125-88; Eric Josef Carlson, Marriage and the English Reformation (Oxford, 1994); Lawrence Stone, Road to divorce (Oxford, 1990), pp. 139-230, 301-22; idem, Uncertain unions (Oxford, 1992); idem, Broken lives (Oxford, 1993); see also Bernard Capp, When gossips meet. Women, family and neighbourhood in early modern England (Oxford, 2003), pp. 38-42, 118-19.

${ }^{3}$ Stone, Uncertain unions, p. 232; Ingram, Church courts, p. 149, challenged Stone’s earlier remark that bigamy was 'easy and common'. For a good, short discussion of 
bigamy cases in Essex see J. A. Sharpe, Crime in seventeenth-century England. A county study (Cambridge, 1983), pp. 67-8.

${ }^{4}$ Stone, Uncertain unions, pp. 232-74.

${ }^{5}$ Bridewell Court Minutes, Guildhall Library, London, (henceforth GL) MS 33011/6, 8 Sept. 1621; cf. e.g. London Metropolitan Archives (henceforth LMA), MJ/SR 1032/54.

${ }^{6}$ GL, MS 33011/5, fo. 108. On clandestine marriage see R. B. Outhwaite, Clandestine marriage in England 1500-1850 (London, 1995); Stone, Road to divorce, pp. 96-120.

${ }^{7}$ Ingram, Church courts, chs. 4 and 5, passim.

${ }^{8}$ Carlson, Marriage, pp. 75-7, 83-5; Stone, Road to divorce, pp. 301-8, 347-8; Tim Stretton, 'Marriage, separation and the common law in England, 1540-1660', in Helen Berry and Elizabeth Foyster, eds., The family in early modern England (Cambridge, 2007), pp. 18-39.

${ }^{9} 1$ Jac. 1. cap. 11, 'An Act to restrain all persons from marrying until their former wives and former husbands be dead'; English reports, King's bench, 79, pp. 1000-1; 82, p.430; 84, p.1066.

${ }^{10}$ Roderick Phillips, Untying the knot. A short history of divorce (Cambridge, 1991), pp. 22-4; Stone, Road to divorce, pp. 302-3. For divorce in Protestant Germany and Switzerland see Steven Ozment, When fathers ruled (Cambridge, Mass., 1983), pp. 8099; Thomas Safley, Let no man put asunder (Kirksville, Missouri, 1984). 
${ }^{11}$ John Raynolds, A defence of the iudgment of the reformed churches ([Dordrecht], 1609), p.18 and passim; cf. R. G. Usher, ed., The Presbyterian movement in the reign of Queen Elizabeth as illustrated by the minute book of the Dedham classis 1582-1589 (Camden Third Series, vol. 8, London, 1905), pp. 27-8, 36

${ }^{12}$ Edmund Bunny, Of divorce for adulterie (Oxford, 1610), sig. **2v-***.

${ }^{13}$ Stone, Road to divorce, pp.302-3; John Dove, Of diuorcement (London, 1601); John Howson, Uxore dismissa propter fornicationem (Oxford, 1602); Thomas Pye, Epistola ad ... Johannen Housonum (London, 1603). The 1606 edition of Howson's work printed a letter from Rainolds to Pye, supportive but urging restraint: sig. Gg3v-Hh3v.

${ }^{14}$ Ralph Houlbrooke, Church courts and the people during the English reformation 1520-1570 (Oxford, 1979), pp. 70-1.

${ }^{15}$ Bunny, Of divorce, sig. **2v-3v.

${ }^{16}$ John Strype, The life and acts of ... John Whitgift (London, 1718), pp. 508-10, Appendix 36, pp. 222-3; Simonds D’Ewes, The journals of all the parliaments during the reign of Queen Elizabeth (London, 1682), pp. 555-62.

${ }^{17}$ Stone, Road to divorce, pp. 305-6; 1 Jac. 1, c11.

${ }^{18}$ Bunny, Of divorce, sig. ***; William Whately, A bride-bush (London, 1619), pp. 25-8; Whately, A care-cloth (London, 1624), sig. A8-v.

${ }^{19}$ Christopher Maginn, ‘Charles Blount, Lord Mountjoy', in Oxford dictionary of national biography (Oxford, 2004). 
${ }^{20}$ Christopher Durston, The family in the English revolution (Oxford, 1989), ch. 4;

Thomas Edwards, Gangraena (London, 1646), p. 34; Commons journals, vii, p. 388.

${ }^{21}$ LMA, MJ/SR 1258/61; cf. e.g. MJ/SR 1173/50.

${ }^{22}$ Louis A. Knafla, ed., Kent at law (London, 1994), pp. 179, 181.

${ }^{23}$ LMA, MJ/SR 1155/96; cf LMA, MJ/SR 1183/90.

${ }^{24}$ Old Bailey Proceedings (henceforth OB; online at http://oldbaileyonline.org), t16871012-39; t17000115-30.

${ }^{25}$ OB, t16840515-20; cf. LMA, MJ/SR 1064/63; MJ/SR 1115/210.

${ }^{26}$ Mercurius jocosus, 28 July-4 August 1654, pp. 27-8.

${ }^{27}$ Leicestershire Record Office (henceforth LRO), Archdeaconry papers, 1D 41/13/26, fo. $10 \mathrm{v}$

${ }^{28}$ LRO, Hall Papers, BRII/18/13, fo. 478.

${ }^{29}$ GL, MS 33011/4, fos. 184, 194v.

${ }^{30}$ GL, MS 33011/2, fo. 202.

${ }^{31}$ GL, MS 33011/3, 15 August 1579.

32 B. H. Cunnington, ed., Records of the county of Wilts. (Devizes, 1932), pp. 210-11. 
${ }^{33}$ A. J. Willis and Margaret J. Hoad, eds., Portsmouth borough sessions papers 16531688 (London, 1971), pp. 37-8.

${ }^{34}$ LMA, MJ/SR 1114/16.

35 Certain passages, 372 (16-23 March 1655), pagination erratic.

${ }^{36}$ See e.g. Thomas Harman, A caveat for common cursitors (1567) in Gamini Salgado, ed., Cony-catchers and bawdy baskets (Harmondsworth, 1972), pp. 128-37

${ }^{37}$ The last will and testament of Richard Brandon, esquire (London, 1649), p. 7.

${ }^{38}$ The German princess revived (London, 1684), p. 8.

${ }^{39}$ GL, MS 33011/4, fos.161v, 172.

${ }^{40}$ GL, MS 33011/3, f. 327; cf. Laura Gowing, Domestic dangers (Oxford, 1996), pp. 181-2; Stone, Road to divorce, pp. 304-8; Ingram, Church courts, p. 179.

${ }^{41}$ GL, MS 33011/4, fo. 285.

${ }^{42}$ R. Greene, The black bookes messenger (1592), in Salgado, ed., Cony-catchers, pp. $325-6$.

${ }^{43}$ GL, MS 33011/4, fo. 158.

${ }^{44}$ GL, MS 33011/4, fo. 18.

${ }^{45}$ See e.g. Sharpe, Crime, pp. 67-8; Bernard Capp, Cromwell's navy (Oxford, 1989), pp. 252-4. 
${ }^{46}$ See e.g. LMA, MJ/SR 1066/53 (30 year gap); MJ/SR 1071/87 (Barbados); MJ/SR 1093/244 (Dorset); J. S. Cockburn, ed., Calendar of assize records: Kent indictments, Charles I (London, 1995), pp. 102 (Hereford), 515 (Derbyshire); OB, t16891009-5 (Dublin).

47 Perfect proceedings, 299 (13-21 June 1655), p. 4748; Publick intelligencer, 5 (29 Oct.-5 Nov. 1655), pp. 75-6

48 Strange newes from Newgate and the Old-Bailey (London, 1651), 2; Perfect passages, 28 (17-24 Jan. 1651), p. 186; OB, t16840903-15.

${ }^{49}$ Perfect passages, 56 (5-12 March 1652), p. 403; Moderate occurrences, 1 (29 March5 April 1653), p. 8. The Northampton case was deferred as no witnesses appeared.

${ }^{50}$ The faithfull scout, 121 (15-22 July 1653), p. 1087.

${ }^{51} \mathrm{OB}, \mathrm{t} 16760510-1$.

${ }^{52}$ OB, t16991213-39.

${ }^{53} \mathrm{OB}, \mathrm{t} 16920831-12$.

${ }^{54}$ LRO, 1D 41/4/652; Cambridge University Library (henceforth CUL), Ely Diocesan Records (henceforth EDR), D2/11, f.80 (a clergyman, 1575); English reports, 78, King's bench, p. 353; LMA, MJ/SR 1088/285; MJ/SR 1148/293. John Bunyan was smeared as a bigamist, witch, highwayman and Jesuit: Bunyan, Grace abounding, ed. Roger Sharrock (Oxford, 1962), p. 93. 
55 J. S. Cockburn, ed., Calendar of assize records: Sussex indictments, James I (London, 1975), 91; cf. LMA, MJ/SR 1183/481; William Le Hardy, ed., Middlesex: calendar to the sessions records, 1612-18 (4 vols., London, 1935-41), ii, pp. 71-2.

56 OB, t16810706a-1.

57 Sharpe, Crime, p. 67; Cockburn, Calendar of assize records: Kent: James I, Charles I,

1649-59, 1660-75, 1676-88 (5 vols., London, 1980-97), passim; Old Bailey Proceedings, passim; LMA, MJ/SR, sessions files 1649-60.

58 GL, MS 33011/7, fo. 187v.

59 Perfect passages, 63 (27 Aug.-3 Sept. 1652), p. 492.

${ }^{60}$ LMA, MJ/SR 1067/52-3.

${ }^{61}$ E.g. LMA, MJ/SR 1046/152, MJ/SR 1050/41.

62 Perfect passages, 39 (11-18 April 1651), p. 278.

63 GL, MS 33011/2, fo. 117.

${ }^{64}$ GL, MS 33011/4, fo. 175v.

65 LRO, BRII/18/24a, fos. 209-11.

66 LMA, MJ/SR 1053/38; cf. MJ/SR 1043/183; MJ/SR 1152/41a.

67 GL, MS 33011/4, fos. 193v-4. 
${ }^{68}$ Bernard Capp, 'Republican reformation’, in Berry and Foyster, eds., The family, p. 53.

${ }^{69}$ CUL, EDR, B/21, fo. 75v; GL, MS 33011/8, fo.110.

${ }^{70}$ LRO, 1D 41/13/25, fo. 20; cf. 1D 41/13/22, fo. 20; 1D 41/13/24, fo. 7v; 1D 41/13/25, fo. $19 ; 1 \mathrm{D} 41 / 13 / 82$, fo.74.

${ }^{71}$ OB, t16761011-7.

${ }^{72}$ CUL, EDR, B2/21, fo.51v; Edward Burghall, Memorials of the civil war in Cheshire, ed. J. Hall (Record Society of Lancashire and Cheshire, vol. 19, Chester, 1889), p. 6.

${ }^{73}$ e.g. LMA, MJ/SR 1156/265; MJ/SR 1185/269.

${ }^{74}$ LMA, MJ/SR 1115/245; cf. MJ/SR 1117/81.

${ }^{75}$ J. S. Cockburn, ed., Calendar of assize records: Surrey indictments, James I (London, 1982), pp. 230, 253; idem, Calendar of assize records: Kent indictments, James I

(London, 1980), p. 136; idem, Calendar of assize records: Kent indictments, 1649-59 (London, 1989), p. 131.

${ }^{76}$ LMA, MJ/SR 1071/87.

${ }^{77}$ F. J. C. and D. M. Hearnshaw, eds., Court leet records, part iii, 1603-24 (Southampton Record Society, Southampton, 1907), p. 392.

${ }^{78}$ LRO, BRII/18/5/802.

${ }^{79}$ GL, MS 33011/3, fo.183. 
${ }^{80}$ LRO, 1D 41/13/57, fo. 267; cf. CUL, EDR D2/9, fo.139v.

${ }^{81}$ LRO, 1D 41/13/39, f.62. For a failed attempt to purge see 1D 41/13/59, fo. 41.

${ }^{82}$ LRO, 1D 41/13/12, f.33v; cf.1D 41/13/26, f.18.

${ }^{83}$ W. L. Sachse, ed., Minutes of the Norwich court of mayoralty 1632-1635 (Norfolk Record Society, vol. 36, Norwich, 1967), p. 124.

${ }^{84}$ LRO, BRII/18/11/171-2.

${ }^{85}$ E.g. J. S. Cockburn, ed., Calendar of assize records: Essex indictments, James I (London, 1982), p. 39; OB, t16800115-5, t16830712-12.

${ }^{86}$ The Old Bailey records are incomplete, and the figures exclude three men discharged under royal pardons, and a Jewish man whose case fell outside the scope of the Act.

${ }^{87}$ Cockburn, Calendar: Kent, Charles I, pp. 233-5, 457; idem, Calendar: Kent, 1649-59, p.131; idem, Calendar of assize records: Kent indictments 1676-88 (London, 1997), pp. $66,181-2$

${ }^{88}$ E.g. OB, t16741014-4; t16761011-7, 8; t16820223-5; t16831212-26; t16850225-8; t17000828-42.

${ }^{89}$ OB, t16910115-20.

${ }^{90}$ E.g. OB, t16820916-8; t16820916a-8.

${ }^{91}$ OB, t16870406-33. 
92 E.g. OB, t16891211-28.

93 OB, t16811017a-4.

94 OB, t16820916-8; t16820916a-8; cf. t16811017a-4.

95 OB, t16861013-21.

96 Outhwaite, Clandestine marriage, pp. 24-31; David M. Turner, Fashioning adultery (Cambridge, 2002), pp. 68-73

97 OB, t16920115-18.

98 OB, t16880711-20; t16871012-39; t16930426-27.

99 LRO, 1D 41/13/26, fo.16v.

100 E.g. GL, MS 33011/1, fo. 205v; MS 33011/3, fos. 183, 184-v, 187v.

101 GL, MS 33011/3, fo. 326.

102 GL, MS 33011/3, 12, 14, 15 August 1579.

103 OB, t16920831-12.

104 E.g. Cunnington, ed., Records of Wilts, pp. 60-1; Cockburn, Calendar: Surrey, James I, pp. 7, 8; idem, Calendar: Essex, James I, pp. 191, 249, 258.

105 OB, t16760510-1; t16931206-14.

106 Cockburn, Calendar: Kent, 1649-59, p. 131. 
107 J. C. Jeaffreson, ed., Middlesex county records (4 vols., London, 1886-92), ii, p.27; OB, t16930906-25.

108 Cockburn, Calendar: Essex, James I, p. 191; LMA, MJ/SR 1071/33; OB, t167606286; t16770711a-6.

109 Cockburn, Calendar: Surrey: James I, pp. 7, 8.

110 J. S. Cockburn, ed., Calendar: Kent, Charles I, p. 457.

111 OB, t16760510-2.

112 LMA, MJ/SR 1068/40, 1075/38; on Waterton see Capp, 'Republican reformation’, pp. 43, 65.

113 A perfect diurnall, 36 (12-19 August 1650), p. 433; Perfect passages, 56 (5-12 March 1652), p. 403; Norwich and Norfolk Record Office, Great Yarmouth sessions book, 1651-79, Y/S 1/3, fo.18.

${ }^{114}$ OB, t16920831-12; t16930906-59.

115 OB, t16971208-13.

116 For summaries of colonial American arrangements see Phillips, Untying the knot, pp. 37-45, 69-72; Roger Thompson, Women in Stuart England and America (London, 1974), pp. 174-8. See also John Cairncross, After polygamy was made a sin. The social history of Christian polygamy (London, 1974) 
117 Joanne Bailey, Unquiet lives. Marriage and marriage breakdown in England, 16601800 (Cambridge, 2003), pp. 183-7; Pamela Sharpe, ‘Bigamy among the labouring poor in Essex, 1754-1857’, Local Historian, 24 (1994), pp. 139-45; Ginger Frost, 'Bigamy and cohabitation in Victorian England’, Journal of Family History, 22 (1997), pp. 286-306; cf. Safley, Let No Man, pp. 136-9. 